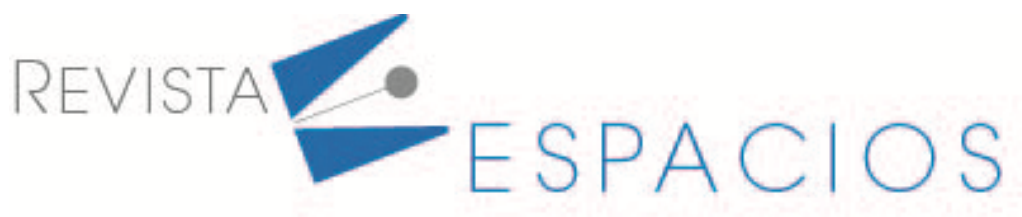

Vol. 42 (02) 2021• Art. 16

Recibido/Received: 06/01/2021 • Aprobado/Approved: 21/01/2021 • Publicado/Published: 31/01/2021

\title{
A science mapping analysis of blood donation behaviour
}

\section{Un análisis de mapeo científico del comportamiento de la donación de sangre}

\author{
PAZ-GIL, Iria ${ }^{1}$ \\ PAULE-VIANEZ, Jessica \\ PRADO-ROMÁN, Alberto ${ }^{3}$
}

\begin{abstract}
This study contributes to the existing literature by providing a current picture of research on blood donation behavior. The methodology applied is a bibliometric analysis, based on scientific production and the science mapping analysis. The analysis is applied over a sample of 963 articles published between 1957 and 2017, in the Web of Science (WoS). Most active journals, authors, countries are identified as well as the main topics in this research area.

key words: blood donation, bibliometric analysis, scientific maps, co-word analysis.

\section{Resumen}

Este estudio contribuye a la literatura existente al proporcionar una imagen actual de la investigación sobre el comportamiento de la donación de sangre. La metodología aplicada es un análisis bibliométrico, basado en la producción científica y el análisis del mapeo científico. El análisis se aplica sobre una muestra de 963 artículos publicados entre 1957 y 2017, en la Web of Science (WoS). Se identifican las revistas, autores, países más activos, así como los principales temas de esta área de investigación.

Palabras clave: donación de sangre, análisis bibliométrico, mapas científicos, análisis de co-ocurrencia de palabras.
\end{abstract}

\section{Introduction}

According to the World Health Organization, donations of blood play an important role on saving lives and improving health, allowing transfusions to people who need them in the clinical practice or elaborate or decompose products derived from the blood.

The study of blood donation is interdisciplinary. Although it's a typical medical matter, social and behavioral sciences contribute to a better understanding of blood donation behavior, to the recruitment of new donors and to the retention of current donors (Ferguson et al., 2007). By the moment is not possible to make blood artificially, so the human donation and posterior transfusion of blood is the only source to treat many patients all over the world.

Academic and social interests in donation of blood make it essential to analyze the state in which the research on blood donation is, what evolution it has had, and which topics are addressed. In this work to clarify the

1 Lecturer in Marketing. Department of Business Economics. Rey Juan Carlos University. iria.paz@urjc.es 2 Lecturer in Finance. Department of Business Economics. Rey Juan Carlos University. jessica.paule@urjc.es

3 Lecturer in Marketing. Department of Business Economics. Rey Juan Carlos University. University.alberto.prado@urjc.es 
evolution of the yield and productivity of the research in this area, as well as to understand the topics that compose it and its situation, it was made a bibliometric analysis, whose main objective is to transform something intangible into a manageable entity (Wallin, 2005). Bibliometrics is a science that allows the treatment and study of quantitative data originating from scientific publications, providing useful and objective tools in scientific activity testing processes (Bordons and Zulueta, 1999). There weren't found other bibliometric analysis of blood donation in the search carried out before starting this study, that aims to provide a wider sight of the research field, to state the main topics, their relationships, and the most cited articles and the most productive authors and journals within the area.

This article is organized as follows: after this introduction begins the methodology; then, data used in the analysis, continuing with the results section; and finally, the discussion of the research.

\section{Methodology}

This study aims to obtain the intellectual structure of the research of blood donation behavior, that contributes to establish the different approaches and their repercussion within this topic. To this end, it was developed a bibliometric analysis using the program Science Mapping Analysis Software Tool (SciMAT v.1.1.04) (Cobo et al., 2012), an open source science mapping software tool developed by the Soft Computing and Intelligent Information Systems research group, University of Granada, Spain (https://sci2s.ugr.es/scimat/index.html).

This bibliometric study was carried out from its two fundamental procedures: the evaluation and analysis of the performance and scientific production through bibliometric indicators, and the creation and analysis of scientific maps (Cobo, 2012).

The analysis of scientific maps (also known as bibliometric maps) is a bibliometric technique whose objective is to monitor a scientific field to understand its structure and evolution, as well as its main participants (Noyons et al., 1999). This technique is carried out using part of the information contained in the documents collected from the bibliographic databases. The different types of information that can be used are known as units of analysis (Paule-Vianez et al., 2020). The analysis unit selected in this paper are the keywords.

The type of analysis used on the keywords has been the co-occurrence analysis (Callon et al., 1983). There is a co-occurrence relationship between two elements when both appear together in a document. There will be a relationship of co-occurrence between two elements $i$ and $j$ if both elements appear in the same document. This analysis helps to identify the basic topics of a scientific field showing conceptual and cognitive aspects of it (Cobo, 2012).

The bibliometric network is obtained through the co-occurrence relations of keywords. Afterwards the network is normalized, that allows using in the analysis strongest relations between keywords. To relativize the connections between two units of analysis, there are given greater importance to those units with a low frequency, but with a high frequency of co-appearance, compared to those units with a high frequency but a low frequency of co-appearance (Cobo, 2012).

Once the network is normalized, it can be created the scientific map, applying clustering techniques with which to divide the set of elements into different subsets, whose nodes (keywords) are strongly linked together (clusters), and poorly linked to the rest. It's used the clustering algorithm based on simple centers, which has the advantage of automatically returning clusters labeled with the most central node of the group (Cobo, 2012).

In each topic network obtained, represented by several nodes, the sphere size of each node is proportional to the number of documents associated with a given keyword. The thickness of the lines between two keywords is proportional to its equivalence index (Figure 1) (Cobo, 2012). 
Figure 1

Structure of a cluster



Source: Cobo (2012)

To evaluate the positioning of each topic in the area, the clusters are represented on the Strategic Diagram, established by Callon et al. (1991), in which different topics are placed according to their centrality ( $x$ axis) and density (y axis). Centrality measures the degree of interaction of a topic with the rest of the topics, meaning the strength of the external links of a topic with the rest. It's defined as: $c=100 \cdot \sum \mathrm{e}_{\mathrm{kh}}$, where $\mathrm{k}$ is a keyword of the cluster and $\mathrm{h}$, a word of another cluster. Thus, centrality allows to evaluate the importance of a topic in the global development of the scientific field. Density measures the degree of internal cohesion of a topic, the internal strength of the different links of the nodes within a cluster. It's defined as $d=100 \frac{\sum e_{i j}}{w}$, where $\mathrm{i}$ and $\mathrm{j}$ are two words belonging to the cluster. Thus, the density of a topic informs of the level of development of this topic. According to this, topics can be classified into four categories (Cobo, 2012) (Figure 2).

Figure 2

Strategic diagram

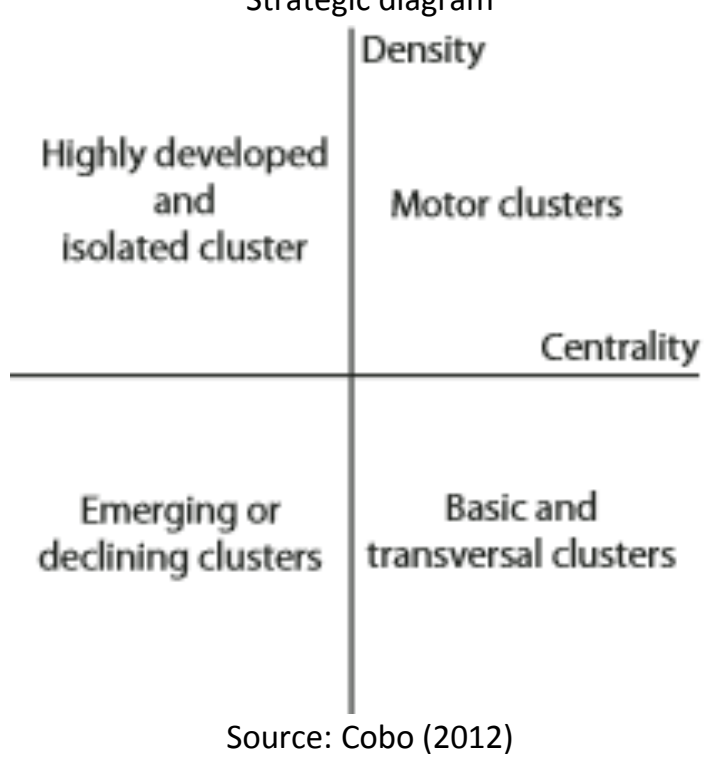

In the upper-right quadrant are placed motor clusters of the area, that have a strong centrality and density and are well developed and important topics in the scientific field. In the upper-left quadrant are shown highly developed and isolated clusters, that are very specialized topics, but not related to the rest, so they have a marginal importance. In the lower-left quadrant appear emerging or declining clusters, that are very underdeveloped and marginal subjects, so they represent emerging or disappearing topics. In the lower-right 
quadrant there are basic and transversal clusters, those very related to the rest, but not well developed themselves, so representing either basic or cross-cutting topics.

\section{Data}

This bibliometric analysis is done over extracted articles published in the Web of Science (WoS) platform of Thomson Reuters, selecting articles published up to 2017 (included) in journals indexed in the Social Sciences Citation Index Database (SSCI). WoS has been selected against other platforms for the number of journals it has collected since 1900.

Data extraction took place on 18 July 2018. The search was done by topics, selecting the papers that contained those concepts in the title, summary and keywords. The query was TS = ("Blood Don*" or "Blood Motiv*" or "Blood Polic*" or "Blood Market *" or "Blood Recruitm*" or "Blood Loyal*"), that throwed a total of 963 articles published up to the year 2017.

\section{Results}

\subsection{Evaluation and analysis of scientific output and production}

The first published article found is "Blood Donor Recruitment: A Case Study in the Psychology of Communication" by Harry A. Grace in 1957. The annual evolution of the publications (Graphic 1), shows a great growth in the research on blood donation. The years with the most publications in the database are 2017 (68 articles), 2016 (62 articles) and 2013 (61 articles). This clarifies an increasing interest in the study of blood donation, demonstrating that it represents an important current of research.

Graphic 1

Evolution of publications in blood donation



Source: Own elaboration

The analysis of the authors shows that five of them have published 134 papers (Table 1), that entail 13,91\% of the total articles published for the studied period. The author who has published more articles indexed in the WoS is Christopher R. France, with 44 documents. 
Table 1

Production of the authors in blood donation

\begin{tabular}{lc}
\hline Authors & No. of Docs. \\
\hline France, Christopher R. & 44 \\
Ditto, Blaine & 24 \\
Ferguson, Eamonn & 23 \\
France, Janis L. & 23 \\
Masser, Barbara M. & 20 \\
\hline
\end{tabular}

Source: Own elaboration

The most cited works has been published in different journals (Table 2). The most cited article is "Relationship between attitudes and evaluative space: a critical review, with emphasis on the separability of positive and negative substrates", by John T. Cacioppo and Gary Berntson (1994), with 850 cites.

Table 2

Most cited articles in blood donation

\begin{tabular}{|c|c|c|c|c|}
\hline Article Title & Authors & Review & Year & $\begin{array}{c}\text { No. of } \\
\text { Cites }\end{array}$ \\
\hline $\begin{array}{l}\text { Relationship between attitudes and } \\
\text { evaluative space: a critical review, with } \\
\text { emphasis on the separability of positive } \\
\text { and negative substrates }\end{array}$ & Cacioppo, Berntson & $\begin{array}{l}\text { Psychological } \\
\text { Bulletin }\end{array}$ & 1994 & 850 \\
\hline $\begin{array}{l}\text { Methodological challenges in research } \\
\text { on sexual risk behavior: II. Accuracy of } \\
\text { self-reports }\end{array}$ & Schroder, Carey, Vanable & $\begin{array}{l}\text { Annals of } \\
\text { Behavioral } \\
\text { Medicine }\end{array}$ & 2003 & 312 \\
\hline $\begin{array}{l}\text { Moral distress of staff nurses in a } \\
\text { medical intensive care unit }\end{array}$ & Elpern, Covert, Kleinpell & $\begin{array}{l}\text { American Journal } \\
\text { of Critical Care }\end{array}$ & 2005 & 177 \\
\hline $\begin{array}{l}\text { Causes of death after diagnosis of } \\
\text { hepatitis B or hepatitis C infection: a } \\
\text { large community-based linkage study }\end{array}$ & $\begin{array}{l}\text { Amin, Law, Bartlett, Kaldor, } \\
\text { Dore }\end{array}$ & Lancet & 2006 & 164 \\
\hline $\begin{array}{l}\text { Crowding out in blood donation: Was } \\
\text { Titmuss right? }\end{array}$ & Mellstrom, Johannesson & $\begin{array}{l}\text { Journal of the } \\
\text { European Economic } \\
\text { Association }\end{array}$ & 2008 & 158 \\
\hline $\begin{array}{l}\text { Giving time, money, and blood: } \\
\text { Similarities and differences }\end{array}$ & Lee, Piliavin, Call & $\begin{array}{l}\text { Social Psychology } \\
\text { Quarterly }\end{array}$ & 1999 & 153 \\
\hline $\begin{array}{l}\text { Incidence of hepatitis C virus infection } \\
\text { among injection drug users during an } \\
\text { outbreak of HIV infection }\end{array}$ & $\begin{array}{l}\text { Patrick, Tyndall, Cornelisse, Li, } \\
\text { Sherlock, Rekart, Strathdee, } \\
\text { Currie, Schechter, } \\
\text { O'Shaughnessy }\end{array}$ & $\begin{array}{l}\text { Canadian Medical } \\
\text { Association Journal }\end{array}$ & 2001 & 151 \\
\hline $\begin{array}{l}\text { Identification in } 2 \text { independent samples } \\
\text { of a novel schizophrenia risk haplotype } \\
\text { of the dystrobrevin binding protein gene } \\
\text { (DTNBP1) }\end{array}$ & $\begin{array}{l}\text { Williams, Preece, Morris, } \\
\text { Spurlock, Bray, Stephens, } \\
\text { Norton, Williams, Clement, } \\
\text { Duyer, Curran, Wikinson, } \\
\text { Moskvina, Waddington, } \\
\text { Corvin, Zammit, Kirov, Owen, } \\
\text { O'Donovan }\end{array}$ & $\begin{array}{l}\text { Archives of General } \\
\text { Psychiatry }\end{array}$ & 2004 & 144 \\
\hline $\begin{array}{l}\text { Hepatitis C virus infection and needle } \\
\text { exchange use among young injection } \\
\text { drug users in San Francisco }\end{array}$ & $\begin{array}{l}\text { Hahn, Page-Shafer, Lum, } \\
\text { Ochoa, Moss }\end{array}$ & Hepatology & 2001 & 143 \\
\hline
\end{tabular}




\begin{tabular}{|c|c|c|c|c|}
\hline Article Title & Authors & Review & Year & $\begin{array}{l}\text { No. of } \\
\text { Cites }\end{array}$ \\
\hline $\begin{array}{l}\text { Serotonin transporter gene } \\
\text { polymorphisms, alcoholism, and suicidal } \\
\text { behaviour }\end{array}$ & $\begin{array}{l}\text { Gorwood, Batel, Ades, Hamon, } \\
\text { Boni }\end{array}$ & $\begin{array}{l}\text { Biological } \\
\text { Psychiatry }\end{array}$ & 2000 & 138 \\
\hline $\begin{array}{l}\text { Estimates of infectious disease risk } \\
\text { factors in US blood donors }\end{array}$ & $\begin{array}{l}\text { Williams, Thomson, Schreiber, } \\
\text { Watanabe, Bethel, Lo, } \\
\text { Kleinman, Hollingsworth, } \\
\text { Nemo }\end{array}$ & $\begin{array}{l}\text { Jama-Journal of the } \\
\text { American Medical } \\
\text { Association }\end{array}$ & 1997 & 136 \\
\hline $\begin{array}{l}\text { Depressive distress among } \\
\text { homosexually active african-american } \\
\text { men and women }\end{array}$ & Cochran, Mays & $\begin{array}{l}\text { American Journal } \\
\text { of Psychiatry }\end{array}$ & 1994 & 127 \\
\hline $\begin{array}{l}\text { Motivations to donate blood: } \\
\text { demographic comparisons }\end{array}$ & $\begin{array}{l}\text { Glynn, Kleinman, Schreiber, } \\
\text { Zuck, McCombs, Bethel, } \\
\text { Garratty, Williams }\end{array}$ & Transfusion & 2002 & 126 \\
\hline $\begin{array}{l}\text { Chronic cytomegalovirus infection and } \\
\text { inflammation are associated with } \\
\text { prevalent frailty in community-dwelling } \\
\text { older women }\end{array}$ & $\begin{array}{l}\text { Schmaltz, Fried, Xue, Walston, } \\
\text { Leng, Semba }\end{array}$ & $\begin{array}{l}\text { Journal of the } \\
\text { American } \\
\text { Geriatrics Society }\end{array}$ & 2005 & 125 \\
\hline $\begin{array}{l}\text { The Effects of Acute Stress on } \\
\text { Performance: Implications for Health } \\
\text { Professions Education }\end{array}$ & LeBlanc & Academic Medicine & 2009 & 123 \\
\hline
\end{tabular}

Source: Own elaboration

As for the journals that have published more articles on the subject, a total of 440 appear in the analysis, of which 11 represent $28.36 \%$ of the total papers analyzed (Table 3 ). The journal Transfusion stands out clearly in the area, including 119 blood donation articles (12.36\% of the total).

Table 3

Most productive journals in blood donation

\begin{tabular}{lcccc}
\hline \multicolumn{1}{c}{ Journals } & No. of Docs. & \% & Year Vol 1 & I.F. 2017 \\
\hline Transfusion & 119 & 12,36 & 1961 & 3,423 \\
Vox Sanguinis & 25 & 2,60 & 1956 & 2,107 \\
Transfusion and Apheresis Science & 21 & 2,18 & 1980 & 1,755 \\
Health Psychology & 15 & 1,56 & 1982 & 3,177 \\
Salud Pública de México & 15 & 1,56 & 1959 & 1,039 \\
Revista de Saude Publica & 14 & 1,45 & 1967 & 1,911 \\
Transfusion Medicine & 14 & 1,45 & 1991 & 1,798 \\
Aids Care-Psychological and Socio-Medical & 13 & 1,35 & 1989 & 1,994 \\
Aspects of AIDS/HIV & 13 & 1,35 & 1971 & 1,701 \\
Iranian Journal of Public Health & 12 & 1,25 & 2006 & 2,766 \\
Plos One & 12 & 1,25 & 1967 & 3,007 \\
Social Science and Medicine & 13 & & \\
\hline
\end{tabular}

Source: Own elaboration

The productivity of research by country results from counting the number of documents according to the affiliations of their authors. They are in 88 different countries (Figure 3). United States stands out as the most productive one, with a total of 304 articles, followed by the United Kingdom (122) and other countries all over the world (Table 4). 
Figure 3

Geographical productivity in blood donation.

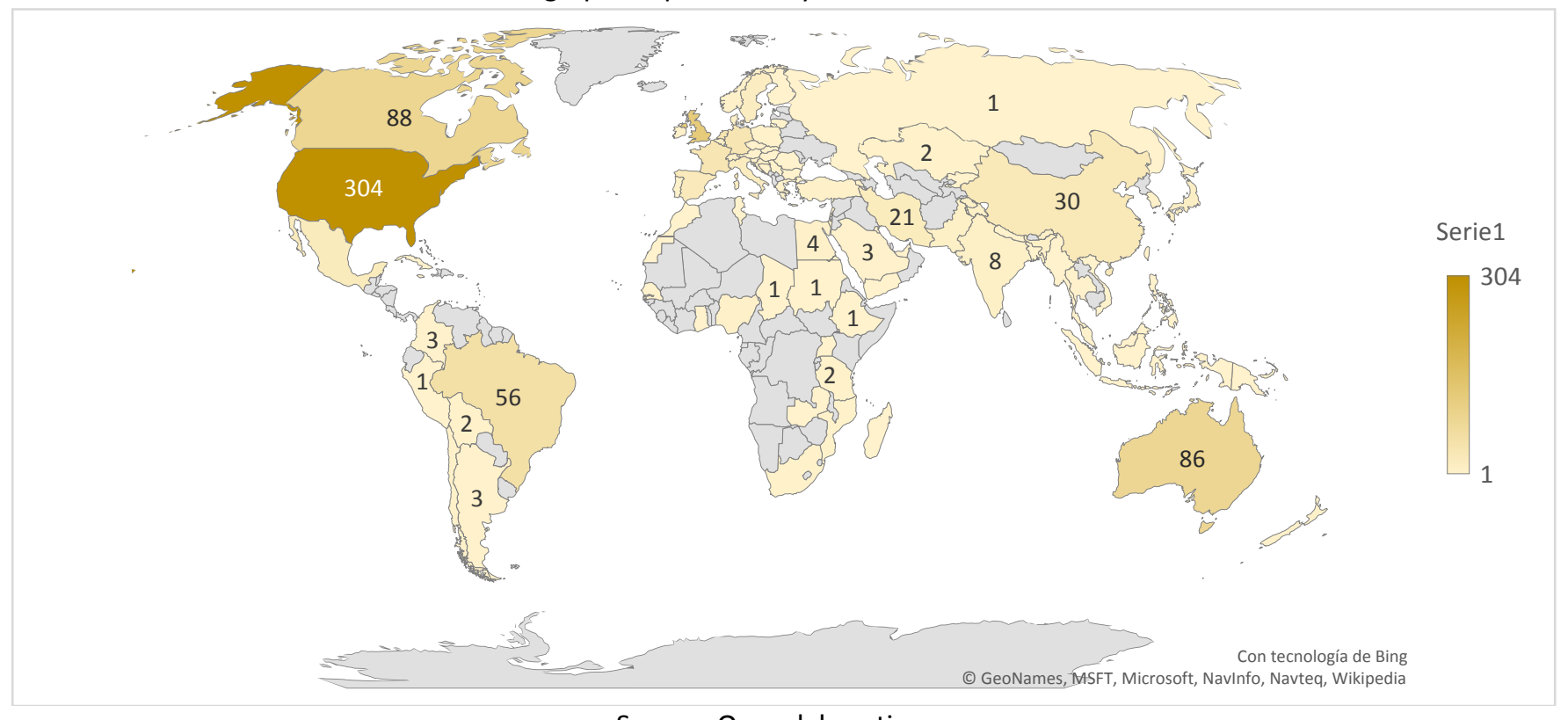

Source: Own elaboration

Table 4

Most productive countries in blood donation

\begin{tabular}{lc}
\hline \multicolumn{1}{c}{ Country } & No. of Docs. \\
\hline United States of America & 304 \\
United Kingdom & 122 \\
Canada & 88 \\
Australia & 86 \\
Brazil & 56 \\
The Netherlands & 41 \\
France & 38 \\
Germany & 38 \\
China & 30 \\
Spain & 26 \\
\hline
\end{tabular}

Source: Own elaboration

\subsection{Creation and analysis of scientific maps}

To extract and evaluate the main topics studied in this field it was applied a co-occurrence analysis of keywords. Selected ones were those used in more than 4 documents, whereof returned a sample of 381 keywords. Applying this technique, there were obtained 10 representative clusters of the main topics that form the research in blood donation (Figure 4). 
Figure 4

Inner composition of each cluster, which shows the relations among topics.

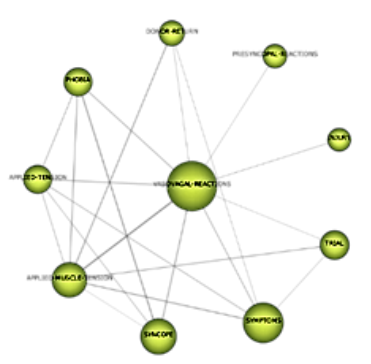

1. Vasovagal Reactions

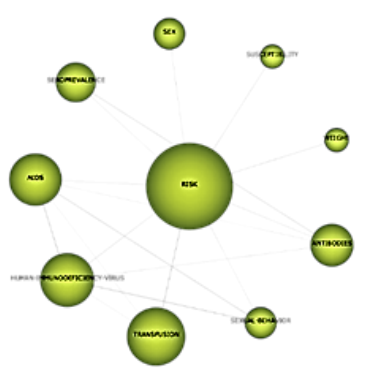

5. Risk



2. Planned Behavior



6. Stress

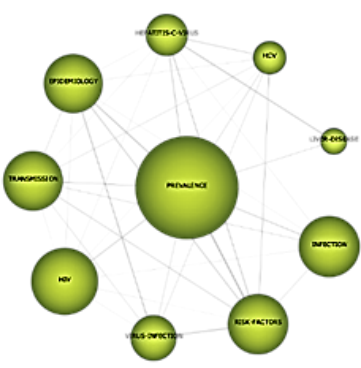

3. Prevalence

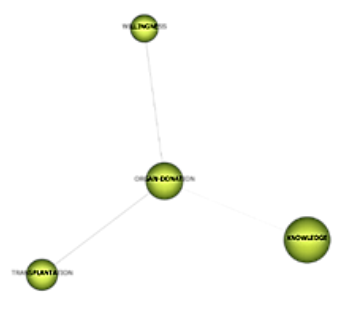

7. Organ Donation



4. Motivation

-





9. Interventions



10. Schizophrenia

Source: Own elaboration

The analysis of the most cited documents of the clusters allows developing the field of research of each one:

1. Vasovagal Reactions: it addresses the study of vasovagal reactions to blood donation and their effects as inhibitors factors among men and women (Fergusson and Bibby, 2002; Ditto et al., 2003; Ditto et al., 2007), and other adverse effects such as anxiety (France et al., 2013). Applied muscle tension is a useful technique to reduce these reactions (Ditto et al., 2003; Ditto et al., 2007). There are exposed different approaches to improve recruitment and retention of blood donors, related to intention (Ferguson and Bibby, 2002; Ferguson et al., 2007) or coping strategies to reduce adverse reactions (France et al., 2008), and the contribution of the theory of planned behavior (TPB) to explain the donation of blood among experienced donors (France et al., 2007).

2. Planned Behavior: it studies the contribution of the TPB to explain the blood donation behavior (BDB) (Lemmens et al., 2009; Masser et al., 2012). Young people behavior responds better to self-efficacy and attitude, personal and subjective norms (perceived social support) (Lemmens et al., 2005; Veludo-deOliveira et al., 2013), while general population's one is better explained by perceived behavioral control, including factors facilitating act, anticipated regret, attitude, moral norms, past experience and level of 
education (Godin et al., 2005; Boenigk et al., 2015), and there also differences between new or experienced blood donors (Lemmens et al., 2009; Boenigk et al., 2015). The benevolence hypothesis, rather than altruism, is supported (Ferguson et al., 2008). The mere measurement effect (Godin et al., 2010) and the improvement of brochures (France et al., 2008) are enforced in the blood donor recruitment field.

3. Prevalence: this cluster is related to risky exposure to blood and blood transmissible diseases. It addresses subjects such as hepatitis $C$ and B infections among drug users' deaths (Hahn et al., 2001; Amin et al., 2006), or hepatitis and HIV infection among injection drug users (Patrick et al., 2001) and other concerns about hepatitis C diagnosis (Shehab et al., 2001) or chronic patients (Gallegos-Orozco et al., 2003). Other important topics treated are educational assessment to drug users and others related to these diseases (Butler et al., 1999; Roy et al., 2001), appropriated screening instruments (Gerbert et al., 1998) and safety and storage conditions of blood banks (Luby et al., 2000).

4. Motivation: it presents finds about motives and obstacles to donate blood (Sojka and Sojka, 2008; Lacetera et al., 2012), like the different crowding out effects of monetary payment (Lacetera and Macis, 2009; Mellstrom and Johannesson, 2008), but not of vouchers (Lacetera and Macis, 2010); or the need to launch differential messages to different groups and to enclose coping strategies to deal with adverse effects (France et al., 2008). There are differences towards blood donation among countries, although in general developing ones donate to get different types of medical information (Goncalez et al., 2008), and economical needs increase contaminated blood donated in the system (Erwin, 2006). There are identified different aspects of altruism explaining BDB (Ferguson et al., 2012), including the benevolence hypothesis (Ferguson et al., 2008; Ferguson et al., 2012) and the contribution to community welfare (Sarason et al., 1993).

5. Risk: it exposes the risks associated with donating blood, like risky behaviors involved in the spread of HIV infection (Cleary et al., 1991; Doll et al., 1991; Doll et al., 1992; White et al., 2007), or the problem of seropositive blood donors during 80's and 90's decades (Cleary et al., 1991; Doll et al., 1992). Related to this, the identified reasons to donate blood are motivated for getting disease screening (Doll et al., 1991; Sharma et al., 2001), and is addressed the willingness to pay for autologous blood donation (Lee et al., 1997). Other concerns in this topic include how to educate in healthy behaviors among infected people (Cleary et al., 1995; White et al., 2007), in prevention (Gerbert et al., 1998; Sharma et al., 2001; White et al., 2007) and in self-exclusion of the donation process (Rugege-Hakiza et al., 2003). It's treated the availability of good measurement instruments around HIV (Gerbert et al., 1998) and presyncopal reactions (France et al., 2008). Antibodies (Cascella et al., 2011) and genes related to schizophrenia (Saadat et al., 2007) and Chagas' disease (Buekens et al., 2008) are also identified.

6. Stress: here blood donation is handled as a stressful situation. Thus, they are exposed fears associated to vasovagal symptoms (Ditto et al., 2012), and their differences associated to baroreflex sensitivity (France, 1995) or cardiovascular offspring reactions (Adler et al., 1994), among others (Kohler et al., 1995). It's pointed out that pain felt during blood extraction is related to anxiety during the process (France et al., 1994). The likelihood of donating again increases when vasovagal symptoms decrease (Sauer and France, 1999) and with social support (Hanson and France, 2009).

7. Organ Donation: it delves into attitude towards organ donation and its psychosocial aspects, like the determinants and barriers to organ donation (Farsides, 2000), including blood donation (Conesa et al., 2005). Factors affecting bone marrow donation (Glasgow and Bello, 2004; Narayanan et al., 2016) and umbilical cord blood donation (Rucinsky et al., 2010) are studied, as well as factors underlying the willingness to living donation (Hyde and White, 2009), and to donate body to science after death according to TPB model (Delaney and White, 2015). It wonders also about ethical concerns of body gifts under an anthropological sight (Simpson, 2004). 
8. Prosocial Behavior: it addresses blood donation as a prosocial behavior, with findings like that symbolic prizes are effective motivators for blood donation when they are publicly announced (social image) (Lacetera and Macis, 2010), that external regulation strategies has negative effects on this behavior, while emphasizing good feelings has a positive one (Pentecost et al., 2017), or that the duration of the wait for donating decreases the likelihood of donation (Craig et al., 2017). Economic incentives increase this likelihood, but not on the long term neither on the safety of collected blood (lajya et al., 2013; Lacetera et al., 2014). Paid blood donation system is defended to correct the imbalance of blood market (Slonim et al., 2014), but unpaid methods are proved to augment the blood supply (Sun et al., 2016).

9. Interventions: it states mainly how the question behavior effect may change health behaviors (Wood et al., 2014; Conner et al., 2017). It can be used both to reactivate lapsed blood donors or to forming implementation intentions (Godin et al., 2014), that together with explicit commitment increases return rates among new donors (Wevers et al., 2015). In the opposite side, others find that questionnaires themselves haven't consequences over BDB (Van Dongen et al., 2013). Directions for evidence-based communication campaigns, avoiding save lives messages (Moussaoui et al., 2016) are given.

10. Schizophrenia: it focuses on mental disorder schizophrenia, with subjects like genes involved in schizophrenia susceptibility (Saadat et al., 2007; Mazaheri and Saadat, 2015), enzymes involved in bipolar disorder among adolescents (Mohammadynejad et al., 2011), homocysteine levels (Ma et al., 2009) or celiac disease (Cascella et al., 2011) among schizophfrenia patients, or the relationship between toxoplasma gondii in schizophrenia patients and suicidal attempts (Ansari-Lari et al., 2017).

These previous clusters are not completely isolated in the field of research, presenting different relations among each other (Table 5). The clusters related to more clusters are Planned Behavior and Motivation. Planned Behavior is related to Vasovagal Reactions, Motivation, Risk, Stress, Organ Donation, Interventions and Schizophrenia. Motivation is related to Vasovagal Reactions, Planned Behavior, Prevalence, Risk, Organ Donation, Prosocial Behavior and Interventions. On the opposite side, the clusters that have less relations with the rest are Stress and Prosocial Behavior. Stress is related to Vasovagal Reactions and Planned Behavior, and Prosocial Behavior is only related to Motivation.

Table 5

Relations among the topics

\begin{tabular}{|c|c|c|c|c|c|c|c|c|c|c|}
\hline Cluster & 1 & 2 & 3 & 4 & 5 & 6 & 7 & 8 & 9 & 10 \\
\hline 1 & & $x$ & & $x$ & & $x$ & & & & \\
\hline 2 & $x$ & & & $x$ & $x$ & $x$ & $x$ & & $x$ & $x$ \\
\hline 3 & & & & $x$ & $x$ & & $x$ & & & \\
\hline 4 & $x$ & $x$ & $x$ & & $x$ & & $x$ & $x$ & $x$ & \\
\hline 5 & & $x$ & $x$ & $x$ & & & $x$ & & & $x$ \\
\hline 6 & $x$ & $x$ & & & & & & & & \\
\hline 7 & & $x$ & $x$ & $x$ & $x$ & & & & & \\
\hline 8 & & & & $x$ & & & & & & \\
\hline 9 & & $x$ & & $x$ & & & & & & $x$ \\
\hline 10 & & $x$ & & & $x$ & & & & $x$ & \\
\hline
\end{tabular}

Source: Own elaboration

Once the clusters and their relations are located, it's essential to evaluate their positioning. For this, the analysis relies on the level of internal development (density) and its influence on the whole area of research (centrality). The most developed clusters themselves are Vasovagal Reactions, Prevalence and Planned Behavior, while those ones with greater influence are Planned Behavior, Prevalence and Motivation. On the other hand, the less 
developed and central clusters are, in different order according to their density and centrality, Interventions, Schizophrenia and Organ Donation (Table 6).

Table 6

Density and centrality of clusters

\begin{tabular}{lcccc}
\hline \multicolumn{1}{c}{ Cluster } & Density & Density Range & Centrality & Centrality Range \\
\hline Vasovagal Reactions & 28,07 & 1 & 11,11 & 0,6 \\
Planned Behavior & 15,56 & 0,8 & 32,38 & 1 \\
Prevalence & 19,6 & 0,9 & 31,88 & 0,9 \\
Motivation & 9,52 & 0,5 & 20,6 & 0,8 \\
Risk & 6,15 & 0,4 & 18,3 & 0,7 \\
Stress & 10,75 & 0,6 & 4,74 & 0,4 \\
Organ Donation & 4,05 & 0,2 & 3,66 & 0,3 \\
Prosocial Behavior & 12,7 & 0,7 & 5,69 & 0,5 \\
Interventions & 5,86 & 0,3 & 1,66 & 0,1 \\
Schizophrenia & 3,76 & 0,1 & 2,53 & 0,2 \\
\hline
\end{tabular}

Source: Own elaboration

Figure 5

Strategic Diagram of the area



Source: Own elaboration 
The strategic diagram, in which the size of the sphere of each cluster indicates the number of documents associated with it, allows to evaluate their position according to their centrality and density (Figure 5). At doing this, it is revealed that the motor clusters of the research in BDB are Vasovagal Reactions, Prevalence and Planned Behavior. These are very developed and very influential topics in the area. The cluster Prosocial Behavior is located between the upper left and right quadrants, so this issue can be considered equally important in the subject, although it isn't as central as the previous ones. Similarly, Motivation is located between the upper right and lower right quadrants, presenting a lower internal development than the rest of the driving topics. As basic and transversal clusters in the area, it only appears the cluster Risk, which, despite being very influential, is not very dense. The only highly developed and isolated cluster found is Stress, which represents a subtopic within the area, but which does not have a high relation with the rest of the topics. Finally, Interventions, Organ Donation and Schizophrenia appear as emerging or declining clusters, according to their levels of density and centrality, and are little developed and little related to the rest topics.

The productivity and the impact of each cluster is evaluated from the number of documents, the $\mathrm{H}$ Index (h articles of the total of the topic that have at least $h$ cites) and the total number of cites (Table 7). Prevalence stands out remarkably over the rest, so much for the number of documents published (133), for the H Index (24), and for the number of cites (2.516).

Table 7

Productivity and impact of each topic

\begin{tabular}{lccc}
\hline \multicolumn{1}{c}{ Cluster } & No. of Docs. & H Index & No. of Cites \\
\hline Vasovagal Reactions & 38 & 16 & 818 \\
Planned Behavior & 98 & 20 & 1.661 \\
Prevalence & 133 & 24 & 2.516 \\
Motivation & 72 & 17 & 1.097 \\
Risk & 76 & 21 & 1.399 \\
Stress & 8 & 7 & 167 \\
Organ Donation & 9 & 6 & 137 \\
Prosocial Behavior & 7 & 4 & 90 \\
Interventions & 7 & 5 & 70 \\
Schizophrenia & 8 & 6 & 190 \\
\hline
\end{tabular}

Source: Own elaboration

The most productive clusters (with the highest number of published articles) are Prevalence (133), Planned Behavior (98) and Risk (76), and clusters with the least number of documents published are Prosocial Behavior and Interventions, with 7 articles each.

Focusing on the impact of the different clusters, those with the highest $\mathrm{H}$ Index are Prevalence (24), Risk (21) and Planned Behavior (20), although according to the number of cites the order varies: Prevalence (2.516), Planned Behavior (1.661) and Risk (1.399). At the other extreme, clusters with lower $\mathrm{H}$ Index and number of cites are Prosocial Behavior and Interventions.

\section{Discussion and conclusions}

The bibliometric analysis of the literature about BDB shows that the firs article indexed in the $\mathrm{SSCl}$ dates to 50 's decade (Grace, 1957) and it already deal with the blood donors recruitment matter, while the most cited one (Cacciopo and Bernston, 1994) provides important advances about attitudes and evaluative processes. The most prolific author, with 44 papers, is France, interested in vasovagal reactions, donor recruitment or TPB, oriented to get and maintain blood donors. 
The area shows a great growth in the studied period, and especially in recent years. Although the number of publications is increasing exponentially in every field of research, the study of BDB represents an important current of research. This is reflected in the fact that there are 440 indexed journals in the WoS that publish papers on this subject, among which Transfusion accounts for $12.36 \%$ of the total of analyzed articles.

By countries, the United States, as it happens in other fields of research, stands out as the most productive country in the area, with 304 papers. It's remarkable that matters around blood donation, BDB and blood safety are a concern all over the world.

The scientific mapping of the selected literature became into 10 representative clusters of the main topics that compose the research in BDB. Vasovagal Reactions states that adverse effects of blood donation act as inhibitor factors, and how to reduce them, and exposes approaches to improve blood donor recruitment and retention. Planned Behavior affirms that TPB contributes to explain the intention to donate blood, but with differences between new and experienced blood donors; it states that the benevolence hypothesis is more supported than the altruism one; and presents methods to improve BDB. Prevalence delves into the huge concern of blood safety. Motivation exposes different motives and obstacles to donate blood among different types of donors; it gives voice to the still living debate about paid vs. voluntary blood donation systems; and keeps delving into different altruism hypothesis to explain, increase or uphold BDB. Risk deeps into risks related to BDB. Stress focuses on stressful aspects of blood donation situation, and their consequences for to repeating or not this behavior. Organ Donation studies attitudes and psychosocial aspects involved in organs donation, including blood donation, and ethical concerns about body gifts. Prosocial Behavior explains the donation of blood through this approach, at the same time that shows opposite stances in favor of or against a paid blood donation system; and the differential effects of external and internal motivation on BDB. Interventions exposes different postures about if the question behavior effect may change or not behaviors and its usefulness to reactivate blood donors; and provides directions for evidence-based communication campaigns. Schizophrenia shows topics related to psychotic disorders.

The analysis of the connections among clusters, along with their density and centrality, enable the identification of the questions the scientific community try to solve. In first place, issues related to the explanation of BDB, both in general or in specific groups, that aims to recruit or retain blood donors. It appears that TPB and different types of altruism fit well with this behavior, and that vasovagal reactions cause many BDB inhibitors. Secondly, subjects around the risk exposure to contaminated blood, like quality of the screening instruments, storage conditions, or educational counselling. Unpaid blood donation systems seem to get safer blood than paid methods. Third, there seems to be differences towards blood donation among certain social groups or even countries. When not otherwise available, blood donation is used to obtain medical information. Lastly, BDB is socially regulated. Social support increases the likelihood to donate, as do so emphasizing good feelings, while bothers around the donation or duty messages decreases it.

Other concerns are related to body parts donation, whether in life or postmortem, and ethical reflections about it. Also, to practical actions to achieve more donors. And finally, issues around psychotic blood measures. The last one (Schizophrenia) is almost certainly a declining cluster in BDB research, because it's not particularly related to this behavior, whereas the other two (Organ-donation and Interventions) may be emerging topics, especially considering that they have the most recent publications. Recent research focuses more on increasing the knowledge of explaining factors of BDB and specific field assays directed towards blood donation raise in many contexts.

The presence on the analysis of papers related to blood diseases, but not to BDB, may be produced by, at least, some articles related to the keyword "prevalence". Further research is required to clarify this aspect, as well as the boundaries between these topics. 
Because of the limits of the search it's known that many good papers are out of the analysis, so further research in given topics will provide a specific wider sight of those points of interest.

Although the limitations of this study, it may help to have a sight of the intellectual structure of BDB research, of its core topics and to enlighten those ones where research efforts are still needed. Future studies based on this one will allow to focus on chosen aspects of BDB. In closing, management and marketing implications, blood donation systems and public policy favoring safe blood self-sufficiency can be drawn.

\section{Bibliographic references}

Adler, P .S. J., Ditto, B., France, C. R., \& France, J. L. (1994). Cardiovascular reactions to blood donation in offspring of hypertensives and normotensives. Journal of Psychosomatic Research, 38(5), 429-439.

Amin, J., Law, M. G., Bartlett, M., Kaldor, J. M., \& Dore, G. J. (2006). Causes of death after diagnosis of hepatitis B or hepatitis C infection: a large community-based linkage study. The Lancet, 368(9539), 938-945.

Ansari-Lari, M., Farashbandi, H., \& Mohammadi, F. (2017). Association of Toxoplasma gondii infection with schizophrenia and its relationship with suicide attempts in these patients. Tropical Medicine and International Health, 22(10), 1322-1327.

Boenigk, S., Mews, M., \& Dekort, W. (2015). Missing minorities: Explaining low migrant blood donation participation and developing recruitment tactics. Voluntas: International Journal of Voluntary \& Nonprofit Organizations, 26(4), 1240-1260.

Bordons, M., \& Zulueta, M. A. (1999). Evaluación de la actividad científica a través de indicadores bibliométricos. Revista Española de Cardiología, 52(10), 790-800.

Buekens, P., Almendares, O., Carlier, Y., Dumonteil, E., Eberhard, M., Gamboa-Leon, R., James, M., Padilla, N., Wesson, D., \& Xiong, X. (2008). Mother-to-child transmission of Chagas' disease in North America: Why don't we do more?. Maternal and Child Health Journal, 12(3), 283-286.

Butler, T., Spencer, J., Cui, J. S., Vickery, K., Zou, J., \& Kaldor, J. M. (1999). Seroprevalence of markers for hepatitis B, C and in male and female prisoners - NSW, 1996. Australian and New Zealand Journal of Public Health, 23(4), 377-384.

Cacioppo, J. T., \& Berntson, G. G. (1994). Relationship between attitudes and evaluative space: A critical review, with emphasis on the separability of positive and negative substrates. Psychological Bulletin, 115(3), 401423.

Callon, M., Courtial, J. P., \& Laville, F. (1991). Co-word analysis as a tool for describing the network of interactions between basic and technological research: The case of polymer chemistry. Scientometrics, 22(1), 155-205.

Callon, M., Courtial, J. P., Turner, W. A., \& Bauin, S. (1983). From translations to problematic networks: An introduction to co-word analysis. Information (International Social Science Council), 22(2), 191-235.

Cascella, N. G., Kryszak, D., Bhatti, B., Gregory, P., Kelly, D. L., Mc Evoy, J. P., Fasano, A., \& Eaton, W. W. (2011). Prevalence of celiac disease and gluten sensitivity in the United States clinical antipsychotic trials of intervention effectiveness study population. Schizophrenia Bulletin, 37(1), 94-100. 
Cleary, P. D., Vandevanter, N., Rogers, T. F., Singer, E., Shiptonlevy, R., Steilen, M., Stuart, A., Avorn, J., \& Pindyck, J. (1991). Behavior changes after notification of HIV-infection. American Journal of Public Health, 81(12), 1586-1590.

Cleary, P. D., Vandevanter, N., Steilen, M., Stuart, A., Shiptonlevy, R., Mcmullen, W., Rogers, T. F., Singer, E., Avorn, J., \& Pindyck, J. (1995). A randomized trial of an education and support program for HIV-infected individuals. AIDS 9(11), 1271-1278.

Cobo, M. J. (2012). SciMat: herramienta software para el análisis de la evolución del conocimiento científico. Propuesta de una metodología de evaluación. Granada: Universidad de Granada.

Cobo, M. J., López-Herrera, A. G., Herrera-Viedma, E., \& Herrera, F. (2012). SciMAT: A new science mapping analysis software tool. Journal of the Association for Information Science and Technology, 63(8), 16091630.

Conesa, C., Rios, A., Ramirez, P., Canteras, A., Rodriguez, A. A., \& Parrilla, P. (2005). Multivariate study of the psychosocial factors affecting public attitude towards organ donation. Nefrologia, 25(6), 684-697.

Conner, M., Sandberg, T., Nekitsing, C., Hutter, R., Wood, C., Jackson, C., Godin, G., \& Sheeran, P. (2017). Varying cognitive targets and response rates to enhance the question-behavior effect: An 8-arm randomized controlled trial on influenza vaccination uptake. Social Science and Medicine, 180, 135-142.

Craig, A. C., Garbarino, E., Heger, S. A., \& Slonim, R. (2017). Waiting to give: Stated and revealed preferences. Management Science, 63(11), 3672-3690.

Delaney, M. F., \& White, K. M. (2015). Predicting people's intention to donate their body to medical science and research. Journal of Social Psychology, 155(3), 221-237.

Ditto, B., France, C. R., Albert, M., \& Byrne, N. (2007). Dismantling applied tension: Mechanisms of a treatment to reduce blood donation-related symptoms. Transfusion, 47(12), 2217-2222.

Ditto, B., Gilchrist, P. T., \& Holly, C. D. (2012). Fear-related predictors of vasovagal symptoms during blood donation: It's in the blood. Journal of Behavioral Medicine, 35(4), 393-399.

Ditto, B., Wilkins, J. A., France, C. R., Lavoie, P., \& Adler, P. S. J. (2003). On-site training in applied muscle tension to reduce vasovagal reactions to blood donation. Journal of Behavioral Medicine 26(1), 53-65.

Doll, L. S., Petersen, L. R., White, C. R., Johnson, E. S., Ward, J. W., Williams, A. E., Altman, R., Becker, G., Bernarducci, J., Busch, M. P., Clary, N., et al. (1992). Homosexually and nonhomosexually identified men who have sex with men - A behavioral-comparison. Journal of Sex Research, 29(1), 1-14.

Doll, L. S., Petersen, L. R., White, C. R., \& Ward, J. W. (1991). Human immunodeficiency virus type 1-infected blood donors: behavioral characteristics and reasons for donation. Transfusion, 31(8), 704-709.

Erwin, K. (2006). The circulatory system: blood procurement, AIDS, and the social body in China. Medical Anthropology Quarterly, 20(2), 139-159.

Farsides, T. (2000). Winning hearts and minds: Using psychology to promote voluntary organ donation. Health Care Analysis, 8(2), 101-121.

Ferguson, E., \& Bibby, P. A. (2002). Predicting future blood donor returns: Past behavior, intentions, and observer effects. Health Psychology, 21(5), 513-518. 
Ferguson, E., Atsma, F., De Kort, W., \& Veldhuizen, I. (2012). Exploring the pattern of blood donor beliefs in first-time, novice, and experienced donors: differentiating reluctant altruism, pure altruism, impure altruism, and warm glow. Transfusion, 52(2), 343-355.

Ferguson, E., Farrell, K., \& Lawrence, C. (2008). Blood donation is an act of benevolence rather than altruism. Health Psychology, 27(3), 327-336.

Ferguson, E., France, C. R., Abraham, C., Ditto, B., \& Sheeran, P. (2007). Improving blood donor recruitment and retention: Integrating theoretical advances from social and behavioral science research agendas.

Transfusion, 47(11), 1999-2010.

France, C. R. (1995). Baroreflex sensitivity during noxious stimulation in vasovagal reactors to blood donation. International Journal of Psychophysiology, 19(1), 13-22.

France, C. R., Adler, P. S. J., France, J. L., \& Ditto, B. (1994). Family History Of Hypertension And Pain During Blood Donation. Psychosomatic Medicine, 56(1), 52-60.

France, C. R., Ditto, B., France, J. L., \& Himawan, L. K. (2008). Psychometric properties of the Blood Donation Reactions Inventory: a subjective measure of presyncopal reactions to blood donation. Transfusion, 48(9), 1820-1826.

France, C. R., France, J. L., Wissel, M. E., Ditto, B., Dickert, T., \& Himawan, L. K. (2013). Donor anxiety, needle pain, and syncopal reactions combine to determine retention: a path analysis of two-year donor return data. Transfusion, 53(9), 1992-2000.

France, C. R., Montalva, R., France, J. L., \& Trost, Z. (2008). Enhancing attitudes and intentions in prospective blood donors: evaluation of a new donor recruitment brochure. Transfusion, 48(3), 526-530.

France, J. L., France, C. R., and Himawan, L. K. (2007). A path analysis of intention to redonate among experienced blood donors: an extension of the theory of planned behavior. Transfusion, 47(6), 1006-1013.

Gallegos-Orozco, J. F., Fuentes, A. P., Argueta, J. G., Perez-Pruna, C., Hinojosa-Becerril, C., Sixtos-Alonso, M. S., Cruz-Castellanos, S., Gutierrez-Reyes, G., Olivera-Martinez, M. A., Gutierrez-Ruiz, M. C., et al. (2003). Health-related quality of life and depression in patients with chronic hepatitis C. Archives of Medical Research, 34(2), 124-129.

Gerbert, B., Bronstone, A., McPhee, S., Pantilat, S., \& Allerton, M. (1998). Development and testing of an HIVrisk screening instrument for use in health care settings. American Journal of Preventive Medicine, 15(2), 103-113.

Glasgow, M., \& Bello, G. (2007). Bone marrow donation: factors influencing intentions in African Americans. Oncology Nursing Forum, 34(2), 369-377.

Godin, G., Germain, M., Conner, M., Delage, G., \& Sheeran, P. (2014). Promoting the return of lapsed blood donors: A seven-arm randomized controlled trial of the question-behavior effect. Health Psychology, 33(7), 646-655.

Godin, G., Sheeran, P., Conner, M., Delage, G., Germain, M., Belanger-Gravel, A., \& Naccache, H. (2010). Which survey questions change behavior? Randomized controlled trial of mere measurement interventions. Health Psychology, 29(6), 636-644. 
Godin, G., Sheeran, P., Conner, M., Germain, M., Blondeau, D., Gagne, C., Beaulieu, D., \& Naccache, H. (2005). Factors explaining the intention to give blood among the general population. Vox Sanguinis, 89(3), 140149.

Goncalez, T. T., Sabino, E. C., Chen, S., Salles, N. A., Chamone, D. A. F., McFarland, W., \& Murphy, E. L. (2008). Knowledge, attitudes and motivations among blood donors in Sao Paulo, Brazil. AIDS and Behavior, 12(4), S39-S47.

Grace, H. A. (1957). Blood donor recruitment: a case study in the psychology of communication. The Journal of Social Psychology, 46(2), 269-276.

Hahn, J. A., Page-Shafer, K., Lum, P. J., Ochoa, K., \& Moss, A. R. (2001). Hepatitis C virus infection and needle exchange use among young injection drug users in San Francisco. Hepatology, 34(1), 180-187.

Hanson, S. A., \& France, C. R. (2009). Social support attenuates presyncopal reactions to blood donation. Transfusion, 49(5), 843-850.

Hyde, M. K., \& White, K. M. (2009). Knowing a donor and identifying as one: Determinants of people's willingness for related and anonymous living donation in Australia. Psychology Health and Medicine, 14(5), 524-535.

lajya, V., Lacetera, N., Macis, M., \& Slonim, R. (2013). The effects of information, social and financial incentives on voluntary undirected blood donations: Evidence from a field experiment in Argentina. Social Science and Medicine, 98, 214-223.

Kohler, T., Scherbaum, N., \& Ritz, T. (1995). Psychophysiological responses of borderline hypertensives in two experimental situations. Psychotherapy and Psychosomatics, 63(1), 44-53.

Lacetera, N., \& Macis, M. (2009). Do all material incentives for pro-social activities backfire? The response to cash and non-cash incentives for blood donations. Journal of Economic Psychology, 31(4), 738-748.

Lacetera, N., \& Macis, M. (2010). Social image concerns and prosocial behavior: Field evidence from a nonlinear incentive scheme. Journal of Economic Behavior and Organization, 76(2), 225-237.

Lacetera, N., Macis, M., \& Slonim, R. (2012). Will there be blood? Incentives and displacement effects in prosocial behavior. American Economic Journal-economic Policy, 4(1), 186-223.

Lacetera, N., Macis, M., \& Slonim, R. (2014). Rewarding volunteers: A field experiment. Management Science, 60(5), 1107-1129.

Lee, S. J., Neumann, P. J., Churchill, T. H., Cannon, M. E., Weinstein, M. C., \& Johannesson, M. (1997). Patients' willingness to pay for autologous blood donation. Health Policy, 40(1), 1-12.

Lemmens, K. P. H., Abraham, C., Hoekstra, T., Ruiter, R. A. C., De Kort, W., Brug, J., \& Schaalma, H. P. (2005). Why don't young people volunteer to give blood? An investigation of the correlates of donation intentions among young nondonors. Transfusion, 45(6), 945-955.

Lemmens, K. P. H., Abraham, C., Ruiter, R. A. C., Veldhuizen, I., Dehing, C., Bos., A., \& Schaalma, H. P. (2009). Modelling antecedents of blood donation motivation among non-donors of varying age and education. British Journal of Psychology, 100, 71-90. 
Luby, S., Khanani, R., Zia, M., Vellani, Z., Ali, M., Qureshi, A. H., Khan, A. J., Mujeeb, S. A. Shah, S. A., \& FisherHoch, S. (2000). Evaluation of blood bank practices in Karachi, Pakistan, and the government's response. Health Policy and Planning, 15(2), 217-222.

Ma, Y. Y., Shek, C. C., Wong, M. C. K., Yip, K. C., Ng, R., Nguyen, D., \& Poon, T .K. (2009). Homocysteine level in schizophrenia patients. Australian and New Zealand Journal of Psychiatry 43(8), 760-765.

Masser, B. M., Bednall, T. C., White, K. M., \& Terry, D. J. (2012). Predicting the retention of first-time donors using an extended Theory of Planned Behavior. Transfusion, 52(6), 1303-1310.

Mazaheri, H., \& Saadat, M. (2015). Association between insertion/deletion polymorphism in angiotension converting enzyme and susceptibility to schizophrenia. Iranian Journal of Public Health, 44(3), 369-373.

Mellström, C., and Johannesson, M. (2008). Crowding out in blood donation: was Titmuss right?. Journal of the European Economic Association, 6(4), 845-863.

Mohammadynejad, P., Saadat, I., Ghanizadeh, A., \& Saadat, M. (2011). Bipolar disorder and polymorphisms of glutathione S-transferases M1 (GSTM1) and T1 (GSTT1). Psychiatry Research, 186(1), 144-146.

Moussaoui, L. S., Naef, D., Tissot, J. D., \& Desrichard, O. (2016). "Save lives" arguments might not be as effective as you think: A randomized field experiment on blood donation. Transfusion Clinique Et Biologique, 23(2), 59-63.

Narayanan, P., Wolanskyj, A., Ehlers, S. L., Litzow, M. R., Patnaik, M. S., Hogan, W. J., \& Hashmi, S. K. (2016). Medical students' knowledge, familiarity, and attitudes towards hematopoietic stem cell donation: stem cell donation behaviors. Biology of Blood and Marrow Transplantation, 22(9), 1710-1716.

Noyons, E. C., Moed, H. F., \& Luwel, M. (1999). Combining mapping and citation analysis for evaluative bibliometric purposes: A bibliometric study. Journal of the Association for Information Science and Technology, 50(2), 115-131.

Patrick, D. M., Tyndall, M. W., Cornelisse, P. G., Li, K., Sherlock, C. H., Rekart, M. L., Strathdee, S. A., Currie, S. L., Schechter, M. T., \& O'Shaughnessy, M. V. (2001). Incidence of hepatitis C virus infection among injection drug users during an outbreak of HIV infection. Canadian Medical Association Journal, 165(7), 889-895.

Paule-Vianez, J., Gómez-Martínez, R., \& Prado-Román, C. (2020). A bibliometric analysis of behavioural finance with mapping analysis tools. European Research on Management and Business Economics. 26(2), 71-77-

Pentecost, R., Arli, D., and Thiele, S. (2017). It's my choice! Investigating barriers to pro-social blood donating behaviour. Marketing Intelligence and Planning, 35(2), 243-258.

Roy, E., Haley, N., Leclerc, P., Boivin, J. F., Cedras, L., \& Vincelette, J. (2001). Risk factors for hepatitis C virus infection among street youths. Canadian Medical Association Journal, 165(5), 557-560.

Rucinski, D., Jones, R., Reyes, B., Tidwell, L., Phillips, R., \& Delves, D. (2010). Exploring opinions and beliefs about cord blood donation among Hispanic and non-Hispanic black women. Transfusion, 50(5), 1057-1063.

Rugege-Hakiza, S. E., Glynn, S. A., Hutching, S. T., Bethel, J., Nass, C., McEntire, R. L., Hirschler, N. V., Campbell, J. G., Ladavac, A., \& Schreiber, G. B. (2003). Do blood donors read and understand screening educational materials?. Transfusion, 43(8), 1075-1083.

Saadat, M., Mobayen, F., \& Farrashbandi, H. (2007). Genetic polymorphism of glutathione S-transferase T1: a candidate genetic modifier of individual susceptibility to schizophrenia. Psychiatry Research, 153(1), 87-91. 
Sarason, I. G., Sarason, B. R., Slichter, S. J., Beatty, P. G., Meyer, D. M., \& Bolgiano, D. C. (1993). Increasing participation of blood donors in a bone-marrow registry. Health Psychology, 12(4), 272-276.

Sauer, L. A., \& France, C. R. (1999). Caffeine attenuates vasovagal reactions in female first-time blood donors. Health Psychology, 18(4), 403-409.

Sharma, U. K., Schreiber, G. B., Glynn, S. A., Nass, C., Higgins, M. J., Tu, Y., Bethel, J., \& Williams, A. E. (2001). Knowledge of HIV/AIDS transmission and screening in United States blood donors. Transfusion, 41(11), 1341-1350.

Shehab, T. M., Sonnad, S. S., \& Lok, A. S. F. (2001). Management of hepatitis C patients by primary care physicians in the USA: results of a national survey. Journal of Viral Hepatitis, 8(5), 377-383.

Simpson, B. (2004). Impossible gifts: bodies, Buddhism and bioethics in contemporary Sri Lanka. Journal of the Royal Anthropological Institute, 10(4), 839-859.

Slonim, R., Wang, C., \& Garbarino, E. (2014). The market for blood. Journal of Economic Perspectives, 28(2), 177-196.

Sojka, B. N., \& Sojka, P. (2008). The blood donation experience: self-reported motives and obstacles for donating blood. Vox Sanguinis, 94(1), 56-63.

Sun, T. S., Lu, S. F., \& Jin, G. Z. (2016). Solving shortage in a priceless market: Insights from blood donation. Journal of Health Economics, 48, 149-165.

Van Dongen, A., Abraham, C., Ruiter, R. A. C., \& Veldhuizen, I. J. T. (2013). Does questionnaire distribution promote blood donation? An investigation of question-behavior effects. Annals of Behavioral Medicine, 45(2), 163-172.

Veludo-de-Oliveira, T., Pallister, J. G., \& Foxall, G. R. (2013). Accounting for sustained volunteering by young people: An expanded TPB. Voluntas: International Journal of Voluntary and Nonprofit Organizations, 24(4), 1180-1198.

Wallin, J. A. (2005). Bibliometric methods: pitfalls and possibilities. Basic and Clinical Pharmacology and Toxicology, 97(5), 261-275.

Wevers, A., Wigboldus, D. H. J., Van Den Hurk, K., Van Baaren, R., \& Veldhuizen, I. J. T. (2015). Increasing firsttime blood donation of newly registered donors using implementation intentions and explicit commitment techniques. Vox Sanguinis, 108(1), 18-26.

White, E. F., Garfein, R. S., Brouwer, K. C., Lozada, R., Ramos, R., Firestone-Cruz, M., Perez, S. G., MagisRodriguez, C., Conde-Gonzalez, C. J., \& Strathdee, S. A. (2007). Prevalence of hepatitis C virus and HIV infection among injection drug users in two Mexican cities bordering the US. Salud Publica De Mexico, 49(3), 165-172.

Wood, C., Conner, M., Sandberg, T., Godin, G., \& Sheeran, P. (2014). Why does asking questions change health behaviours? The mediating role of attitude accessibility. Psychology and Health, 29(4), 390-404.

Esta obra está bajo una Licencia Creative Commons Attribución-NoCommercial 4.0 International 